\title{
A case of newly diagnosed ulcerative colitis presenting with pseudo-membranous enterocolitis followed by CMV colitis complicated with rupture of mitral corda tendinea
}

\author{
Ahmet Yozgat • Selim Demirci • Akif Altinbas • \\ Emin Altiparmak
}

Accepted: 8 January 2015 / Published online: 20 January 2015

(C) Springer-Verlag Berlin Heidelberg 2015

Dear Editor:

The incidence of superinfection of Clostridium difficile (C. difficiele) and cytomegalovirus (CMV)-related colitis in ulcerative colitis (UC) were reported as $1.8-4.6 \%$ and 5$36 \%$, respectively [1-3]. Here, we try to present an UC patients presented with $C$. difficile and then CMV infection, but complicated with an unusual situation, corda tendinea rupture (CTR) in mitral valve.

A 36-year-old woman was admitted to our clinic with 1week durated rectal bleeding and diarrhea 8 to 10 times a day. Physical examination was in normal range. Hb level was $12 \mathrm{gr} / \mathrm{dL}$, sedimentation rate $22 \mathrm{~mm} / \mathrm{Hg}$, and C-reactive protein $22 \mathrm{mg} / \mathrm{L}$. Stool culture did not reveal any bacterial infection and $C$. difficile toxin A and Entamoeba hystolytica antigen in stool were negative. After the diagnosis of UC was taken, mesalazin $4000 \mathrm{mg}$ /day was started. Recurrent fever reaching $38.3{ }^{\circ} \mathrm{C}$ appeared at the 3 rd day of therapy. Even with wide investigation, a source of infection cannot be defined. Therefore, prednisolone was started in the diagnosis of severe UC at the 7th day of therapy. At the 5th day of prednisolone treatment, second colonoscopy determined yellowish white plaques within 5 to 20 -mm diameter. Prednisolone was stopped immediately and oral vancomycin was initiated. At the next day, a sudden shortness of breath and tachycardia appeared. The patient underwent immediate mitral valve repair surgery due to the findings of new TTE, a rupture of mitral corda tendinea. Then after, CMV DNA viral load was found as 269 copy $/ \mathrm{mL}$, and because of ongoing fever, intravenous ganciclovir was started even the lack of evidence of CMV infection in histopathologic evaluation of colonoscopy. In the upcoming days, both fever and bloody diarrhea were resolved, and the control colonoscopic examination revealed healed colonic mucosa.

\section{References}

1. Issa M, Ananthakrishnan AN, Binion DG (2008) Clostridium difficile and inflammatory bowel disease. Inflamm Bowel Dis 14(10):14321442. doi:10.1002/ibd.20500

2. Hashash JG, Refaat M, Abdulbaki A, Aoun EG, Baidoo L (2012) Cytomegalovirus colitis. Cleve Clin J Med 79(1):12-13. doi:10. 3949/ccjm.78a.11028

3. Kilinçalp S, Altinbaş A, Başar O, Deveci M, Yüksel O (2011) A case of ulcerative colitis co-existing with pseudo-membranous enterocolitis. J Crohn's Colitis 5(5):506-507. doi:10.1016/j.crohns.2011.06.012, Epub 2011 Aug 2
A. Yozgat $\cdot$ S. Demirci $\cdot$ A. Altinbas $\cdot$ E. Altiparmak Gastroenterology Clinic, Numune Education and Research Hospital, Ankara, Turkey

\section{A. Yozgat $(\triangle)$}

Baskent Bulvari 224/B Atlantis City Sítesi, Yosun Blok No. 78

Batkent, Ankara, Turkey

e-mail: a_yozgat@yahoo.com 